This is a self-archived - parallel published version of this article in the publication archive of the University of Vaasa. It might differ from the original.

\title{
Fundamental indexation for developed, emerging, and frontier government bond markets.
}

Author(s): Piljak, Vanja; Swinkels, Laurens

Title: $\quad$ Fundamental indexation for developed, emerging, and frontier government bond markets.

Year: $\quad 2017$

Version: Accepted manuscript

Copyright (C) 2017 Palgrave Macmillan. This is a post-peer-review, precopyedit version of an article published in Journal of Asset Management. The definitive publisher-authenticated version is available online at: https://doi.org/10.1057/s41260-017-00458.

\section{Please cite the original version:}

Piljak, V., \& Swinkels, L., (2017). Fundamental indexation for developed, emerging, and frontier government bond markets. Journal of Asset Management 18(5), 405-420. https://doi.org/10.1057/s41260-017-0045-8 


\title{
Fundamental indexation for
}

\section{developed, emerging, and frontier government bond markets ${ }^{1}$}

\author{
Vanja Piljak \\ University of Vaasa \\ Faculty of Business Studies, Accounting and Finance \\ P.O. Box 700 \\ 65200 Vaasa, Finland \\ vanja.piljak@uva.fi \\ +358294498503 \\ Laurens Swinkels \\ Erasmus University Rotterdam \\ Burgemeester Oudlaan 50 \\ 3062 PA Rotterdam, The Netherlands \\ Iswinkels@ese.eur.nl
}

forthcoming in Journal of Asset Management

\footnotetext{
${ }^{1}$ Swinkels is also affiliated with Robeco Institutional Asset Management. The views expressed in this paper do not necessarily represent those of Robeco. Part of this paper was written when Swinkels was affiliated with Norges Bank Investment Management. We would like to thank seminar participants from University Of Neuchâtel for valuable comments.
} 


\title{
Fundamental indexation for
}

\section{developed, emerging, and frontier government bond markets}

\begin{abstract}
We examine the risk and return characteristics of fundamental weighting schemes for developed, emerging, and frontier government bond markets; and compare these to market capitalization weighted indexes. We document positive excess returns for the investment grade sample only when currency risks are not hedged, suggesting that fundamentals might be more important for currency rather than bond returns. For emerging and frontier markets, we find positive excess returns for fundamental weighting schemes, although not always statistically significant. The excess returns from fundamental weighting schemes for government bonds can be explained by standard factors from equity, currency, or bond markets.
\end{abstract}

Keywords: Bond markets; Currencies; Emerging markets; Fixed income; Investing 


\section{INTRODUCTION}

Arnott et al (2005) have been seminal in the development of valuation-indifferent investment strategies. This type of investment strategies is sometimes referred to as "fundamental indexation", as it offers an alternative to a market capitalization weighted index by using each asset's fundamental value rather than its market price. Individual stocks are weighted by their fundamentals such as their book value, sales, or earnings, instead of using market capitalization weights that might overweight stocks that are overvalued. These valuation-indifferent weighting schemes have historically led to superior performance compared to market capitalization weighted portfolios, mainly because the resulting portfolios are (correlated with) value portfolios (see Perold, 2007; Blitz and Swinkels, 2008).

Arnott et al (2010) apply the same idea of value-indifferent weighting to corporate and sovereign bond markets. They use fundamental values to form bond portfolios and compare these to market-capitalization weighted portfolios. For government bond portfolios, they use the gross domestic product of a country, as well as the population, the (square root of) land area, and energy use. These variables are proxies for the production-capacity of a country, which in turn is positively related to the cash flow it can generate to pay off its government debt. For government bonds, Arnott et al (2010) include only dollar-denominated emerging bond markets in their empirical analysis over the period 1997 to 2009. Shepherd (2012) provides risk and return statistics for fundamentally-weighted sovereign developed and local- and foreigncurrency emerging government bond indexes over the period 1997 to 2011 . De Jong and Wu (2014) extend this work to European corporate and sovereign bond markets. For sovereigns, they limit themselves to GDP-weighting schemes within the Eurozone over the period 2003 to 2013, and find that fundamental indexation leads to significant information ratios. Bolla (2017) 
examines fundamental weighting schemes for 26 countries over the period 1991 to 2014 for government bond returns. Her main finding is that the increased risk exposure explains outperformance of the fundamental indexing methodology in government bond markets. Our paper aims to extend this line of research to global developed and emerging bond markets, in both local currency (currency hedged and unhedged) as well as dollar-denominated debt. Moreover, our sample starts already in 1987 for developed markets, extending the sample period used in prior research. Furthermore, we also analyse frontier markets, which has not been done before in this line of research. Hence, the contribution of this paper is that we provide a comprehensive risk and return analysis of fundamental weighting schemes of sovereign bond markets investable to foreign investors.

We find that fundamental weighting schemes are not providing superior risk-return characteristics compared to market-capitalisation weighting schemes. We document 0.80 percent per annum excess return for our sample of investment grade government bonds when currency risks are not hedged, while this is 0.03 percent per annum when currency risks are hedged. For our shorter local-currency emerging markets sample we find that unhedged excess returns are 1.06 percent, while hedged excess returns only 0.49 . These results suggest that currency forward returns and not fixed income returns are related to country fundamentals. For our samples of USD-denominated emerging markets and frontier bonds, we report excess returns of 0.87 and 0.19 percent per annum, respectively. When we adjust the excess returns for well-known factors from equity, currency, or bond markets, the alphas become close to zero and are almost always statistically no longer significant. 
Our study differs from previous studies in at least three key aspects. First, our paper is the first to include the category of frontier government bond markets. ${ }^{2}$ This is important, as the size of government debt related to country fundamentals differs substantially in these markets, thus providing valuable information for an out-of-sample analysis. Second, our study adds to previous literature by examining the currency aspect of investing in foreign bond markets. In previous literature, this was somewhat less important, as Arnott et al (2010) focus only on dollardenominated emerging bond markets, while De Jung and Wu (2014) cover only European government bond markets. Shepherd (2012) performs analysis of developed and emerging markets, also in local currency emerging bond markets, but his study does not include statistical analyses of the relative performances versus market-capitalization weighted indexes, nor include analyses on the influence of foreign currencies. Third, our paper contains a detailed analysis of bond, equity, and currency risk factor exposures of fundamental weighting schemes. Bolla (2017) also provides an analysis of risk exposures of fundamentally weighted government bond strategies, but her study and its direct implications are limited to government bond markets of developed countries only. Taken together, our paper contains the most comprehensive set of bond markets and most comprehensive set of risk analyses thus far reported in the literature.

This paper is organized as follows. The upcoming section contains data and the descriptive statistics of each group of sovereign bond markets we consider, while the next section presents the analysis of the risk and return of each of the fundamental weights in relation to the market-

\footnotetext{
${ }^{2}$ The frontier government bond markets have recently attracted interest of international investors since those markets are among the world's fastest-growing economies, in which government bonds are becoming an increasingly important source of financing. In addition, diversification potential of traditional emerging market debt issuers has been diminishing due to their increased correlation with developed bond markets, which directed investors to look for new alternative issuers (see, for example, Reuters, 22 November 2012: "And the winner is - frontier market bonds"). For more comprehensive overview of frontier government bond markets, see Piljak and Swinkels (2015).
} 
capitalization-weighted portfolio. The following section relates the returns of these fundamental government bond strategies to factors from equity, currency, and bond markets. The last section provides conclusions.

\section{DATA AND DESCRIPTIVE STATISTICS}

We distinguish four groups of bond markets that come from two different data sources. First, the sample we label "Investment Grade" contains all fixed-rate local currency government bonds with investment grade rating and a bond market that is easily accessible for foreign investors. The data source is Barclays and contains all constituent countries from the Barclays Global Treasury Index, which was established by Lehman Brothers in 1992 and backfilled until January 1987. ${ }^{1}$ Within each country, the bonds are weighted by market capitalization. This means that the weighted average remaining maturity differs from country to country based on their issuance patterns. ${ }^{2}$ Thomas and Bennyhoff (2012) show that fundamentally-weighted fixed income indexes often boil down to underweighting the United States and Japan and overweighting emerging markets. Hence, separating investment grade and emerging markets in our analyses might limit the overweight to emerging markets somewhat.

Second, the sample we label "Emerging Markets Local" contains all investable fixed-rate local currency treasury bonds from emerging markets that satisfy certain size and investability criteria. This data is from Barclays Emerging Markets Local Government Universal Index and starts in July 2008. Within each country, the bonds are weighted by market capitalization.

Third, the sample we label "Emerging Markets USD" contains all investable USDdenominated bonds issued on international markets by emerging markets. This data is from the J.P. Morgan EMBI+ index and starts at the end of 1993. The EMBI+ tracks total returns for US 
dollar-denominated debt instruments issued by emerging market sovereign and quasi-sovereign entities, including Brady bonds, loans, and Eurobonds. Within each country, the bonds are weighted by market capitalization.

Fourth, the sample we label "Frontier Markets USD" contains all investable bonds denominated in USD issued on international markets by frontier markets, the next generation of emerging markets. This data is from J.P. Morgan, and contains the constituents of their NEXGEM index, which was launched in 2011 and backfilled until the end of 2001. The NEXGEM index tracks US dollar-denominated debt issued by sovereign and quasi-sovereign issuers. The country must have a rating of $\mathrm{Ba} 1 / \mathrm{BB}+$ or lower by both Moody's and S\&P to be classified as a frontier market. Within each country, the bonds are weighted by market capitalization. This is the same sample as used in Piljak and Swinkels (2015).

In the Appendix we display for each sample a table that contains the starting date, annualized average return, annualized standard deviation, minimum and maximum on monthly returns of each country, as well as market characteristics (average yield, average maturity, and market capitalization). We take the perspective of an investor with the USD as home currency. For international bonds in local currency, we use both returns hedged to USD using currency derivatives and unhedged in USD. The latter returns are more volatile because of the volatility of the exchange rate, which is typically about twice the volatility of the bond market.

Similar to Arnott et al (2010), we use fundamental factors that are proxies for the current and potential importance of a country in the world economy. The following four factors are the same as in Arnott et al (2010): total population, land area, gross domestic product, and energy consumption. We tried another fundamental factor "natural resources", which should serve as a more advanced proxy for resources as "land area", which is used by Arnott et al (2010). 
However, since its performance is typically worse than land area, we do not include the results. The composite indicator is the equally-weighted combination of the four fundamental factors as in Arnott et al (2010). The data on the fundamental factors are from the World Bank (the World Development Indicators), with the exception of energy consumption data which are from the 2016 British Petroleum Statistical Review of World Energy.

Note that we do not include characteristics that do not directly relate to the fundamental value of a country, such as its credit rating, interest rates, or political risk score (see, e.g., Ilmanen, 1995; Ilmanen and Sayood, 2002; Duyvesteyn and Martens, 2014; Duyvesteyn et al, 2016). Thomas and Bennyhoff (2012) indicate that these could be important for expected returns on these international bond markets. However, these measures do not refer to the economic fundamental importance of a country. For example, the weight of an economically small country with an AAA-rating would be the same as that of an economically large country with an AAArating.

\section{RISK AND RETURN OF FUNDAMENTAL WEIGHTING SCHEMES}

In this section, we analyse the risk and return characteristics of fundamental weighting schemes and compare these to a market-capitalisation weighted index. The investment strategies are monthly rebalanced strategies with the portfolio weight of each country $i$ at the end of month $t$ to be equal to

$$
w_{i, t}=\frac{F_{i, t}}{\sum_{k=1}^{K} F_{k, t}}
$$


and the total return for fundamental strategy $F$ in month $t$ is

$$
R_{t}^{F}=\sum_{k=1}^{K} w_{k, t-1} \times R_{k, t}
$$

It is important that the weights should be known at the month-end before the returns are measured, such that they can be used in a real-life portfolio context. We abstract from estimating transactions costs in the analyses. Other portfolio characteristics, such as the maturity or yield are calculated in a similar fashion, replacing the return of asset $k$ in period $t$ with the maturity or yield in that period. We also display the Herfindahl Index, a measure of portfolio concentration, as an indication whether the weighting scheme tilts more or less towards countries with large weights in the market capitalization weighted portfolio.

$$
H I_{t}^{F}=\sum_{k=1}^{K} w_{k, t}^{2}
$$

The Herfindahl Index equals unity on a fully concentrated portfolio and $\frac{1}{K}$ for a portfolio with equal weights. Thus, a lower number indicates a higher degree of diversity of the portfolio. This diversity or portfolio concentration is a naive measure of diversification of a portfolio. It is naive in the sense that it only uses weights and does not take into account correlations between assets.

The alphas in this section are estimated with respect to a single factor model $F$, with the market capitalization $(M C)$ weighted bond portfolio the single factor: 


$$
R_{t}^{F}-R_{f, t}=\alpha+\beta \cdot\left(R_{t}^{M C}-R_{f, t}\right)+\varepsilon_{t}^{F}
$$

The tracking error is the standard deviation of the excess return series of the bond portfolio minus the market capitalization weighted index, and the information ratio (IR) the average excess return divided by the tracking error. This measure is closely related to the Sharpe ratio, where the return on the market capitalization weighted portfolio is replaced with the risk-free rate:

$$
I R^{F}=\frac{1}{T} \sum_{t=1}^{T}\left(R_{t}^{F}-R_{t}^{M C}\right) \div \sqrt{\operatorname{Var}\left(R_{t}^{F}-R_{t}^{M C}\right)}
$$

We calculate the performance of the market capitalization-weighted portfolio and compare this to portfolios weighted by the fundamental factors and the equally-weighted composite. We report the results in Tables 1, 2, and 3, where each panel contains a different sample of bond markets or differs with respect to currency hedged or unhedged performance evaluation.

$<$ INSERT TABLE 1 ABOUT HERE >

Table 1 Panel A contains the results for the sample of investment grade government bonds and investigates the currency hedged performance over the period January 1987 until December 2015. The market cap portfolio has a return of 6.17 percent per annum for a volatility of 3.19 
percent. The market cap portfolio has a weighted average maturity of 7.91 years, a yield of 4.33 percent, and a diversity score of 0.19 (with 1.00 being the least diversified portfolio that invests everything in one country). The average return is substantially higher than the average yield, which can be explained by a falling interest rate over this sample period. For each of the four fundamental factors and the equally-weighted composite, the returns are about the same as for the market cap portfolio. The diversity ratio of the composite index equals 0.11 , suggesting that the largest country weights in the market capitalization weighted portfolio are reduced by fundamental weighting, as Thomas and Bennyhoff (2012) indicate.

The highest excess return is 0.04 percent (or 4 basis points) per annum for the land area and energy consumption weighted portfolios. Since the betas for each fundamental factor are slightly above unity (expect for area), the risk-adjusted excess returns or alphas are even smaller or more negative. Hence, our conclusion from Panel A is that for an international local-currency government bond investor who hedges his currency risk, fundamental weighting does not seem to add much value compared to market capitalization weighting.

Table 1 Panel B contains the performance statistics of the same fundamental weighting schemes, but then evaluating the unhedged returns in USD. We see that these results are different from currency hedged returns from Panel $A$. The unhedged returns are much more volatile than hedged returns due to the approximately double volatility of currencies relative to bonds. The excess returns are now between 0.26 and 1.43 percent per year, and the riskadjusted excess return of 1.29 percent per annum is statistically significant at the 5 percent level for the composite. The reason that the alphas are above the excess returns is that the exposures to the market, the betas, are somewhat below unity. The information ratios for the individual factors are between 0.16 and 0.34 , and 0.31 for the composite. From Panel $B$ we conclude that fundamental or value-indifferent weighting schemes for unhedged bond returns are statistically 
significantly higher than for market cap weighting schemes. The combination of Table 1, Panels $A$ and $B$ implies that fundamental weighting might be particularly relevant for currency forward returns, and less so for the bond returns themselves.

< INSERT TABLE 2 ABOUT HERE >

Table 2 Panel A reports the results for the sample of local currency emerging government bonds and investigates the currency hedged performance over the period July 2008 until December 2015. The market cap portfolio has a return of 3.45 percent per annum for a volatility of 2.72 percent. The market cap portfolio has a weighted average maturity of 7.88 years, a yield of 5.57 percent, and a diversity score of 0.13 . The average return is substantially lower than the average yield. This is due the interest differential between many of the emerging markets with the USD, which is effectively the cost of currency hedging. For the most of the four fundamental factors and for the equally-weighted composite, the returns are slightly higher than for the market cap portfolio. The excess returns per annum is negative only for weighted portfolios. Since the estimated betas relative to the market cap portfolio are close to one, and the realized return on the market portfolio is relatively small with 3.45 per cent, the excess returns and alphas are qualitatively the same.

Table 2 Panel B shows the performance statistics of the same fundamental weighting schemes, but then evaluating the unhedged returns in USD. For the unhedged sample, all alphas are positive. The alpha for the Composite indicator is 0.82 . 
$<$ INSERT TABLE 3 ABOUT HERE >

Table 3 Panel A shows the results for the USD-denominated emerging markets government bond index. The volatility of our fundamental weighting schemes is typically larger than the market cap index. The composite index has a volatility of 13.70 percent, while the market cap portfolio has a volatility of 13.46 percent. Arnott et al (2010)'s market cap index had a volatility of 13.87 percent, but their composite fundamental weighting scheme only 11.72 . Our excess returns with respect to the market cap weighted index are all positive (except for energy consumption), but the risk-adjusted excess returns are never statistically significant. While our excess returns and tracking errors are close to Arnott et al (2010), the risk-adjusted excess returns that we find are markedly lower. For example, in their sample "Population" had an excess return of 0.43 percent per annum while we have 1.49 percent per annum. However, they report an alpha of 3.44 percent per annum with a t-statistic of 2.09 , while we estimate alpha to be 1.16 and statistically insignificant with a t-statistic of 1.13 . Therefore, our empirical results only partially support the findings of Arnott et al (2010) for hard-currency emerging government bonds. $^{3}$

Table 3 Panel B shows the results for the USD-denominated frontier markets government bond index. Note that Energy Consumption is missing because for many frontier markets this data is not available. The composite is now the equally-weighted combination of Population, Area, and GDP. For the most of the fundamental factors and for the equally-weighted composite, the returns are higher than for the market cap portfolio, while the volatility is lower. The betas of these fundamental strategies are close to 0.8 , which leads to alphas that are higher than the raw excess returns. For the Composite indicator, the excess return is 0.19 , the alpha 2.20 , and 
corresponding t-statistic 1.94. This suggests that fundamental strategies have higher riskadjusted returns than market cap weighted portfolios for frontier markets at a 10 percent significance level.

\section{FACTOR EXPOSURES OF FUNDAMENTAL GOVERNMENT BOND}

\section{WEIGHTING}

In this section, we investigate in similar spirit to Bolla (2017) to what extend the fundamental weighting schemes are related to known factors in equity, currency, and bond markets. We use four different regression settings and report the results in Table 4 (Panels A, B, C, and D). In the first and the second settings (Panel $A$ and $B$ ), we use the asset pricing model - the Fama and French (1993) three factor model with the excess return on the equity market (RMRF), the return on small stocks minus the return on large stocks (SMB), and the return on value stocks minus the return on growth stocks (HML). We do this for factors derived from US equity markets (Panel A) and from the sample of international stocks markets (Panel B). The data is downloaded from the online data library maintained by Kenneth French. ${ }^{4}$ The US equity sample is available from the start of our sample, but the international series only from July 1990 . The excess return series that we use is the composite fundamental index minus the market capitalization weighted index. The tests we report are based on the regression equation:

$$
R_{t}^{F}-R_{t}^{M C}=\alpha+\beta \cdot R M R F_{t}+\gamma \cdot S M B_{t}+\delta \cdot H M L_{t}+\varepsilon_{t}^{F}
$$


In the third regression setting (Panel C), we use currency factors: the Deutsche Bank value, momentum, and carry factors on the G10 currency universe. We obtain the excess return index series from Bloomberg with codes "DBPPPUSF Index", "DBMOMUSF Index", and "DBHTG10U Index", respectively. These series start in July 1989. The existence of these currency factors is analysed in, for example, Kroencke et al (2014) and Barroso and Santa-Clara (2015).

The fourth regression setting (Panel D) examines the global bond market factors. These are international versions of the term and default factor as discussed in Fama and French (1993). We make the following assumptions about the international factors. We define the term factor as the market capitalization-weighted global nominal local-currency investment grade government bond portfolio. We choose the currency-hedged return on the Barclays Global Treasury Index as a proxy for the long side of the global term factor. Since it is currency hedged, it is the excess bond return in each currency eligible for the index plus the U.S. one-month Treasury bill rate. Since we take the excess return of this index with respect to the U.S. onemonth Treasury bill rate, the resulting factor is a pure global term factor. Our starting point for the default factor is to use the Barclays Global High Yield Index, and before the inception of the global index in September 2000 the Barclays U.S. Corporate High Yield Index. Note that the majority of high yield bonds are issued in USD and EUR; and not in the currency native to the issuer. For the global default factor, we use the excess return on the index relative to currencyand maturity-matched government bonds. This should account for the majority of currency and risk-free interest rate effects in the default factor. To account for currency returns, we choose for the dollar factor the currency return of the global market-capitalization-weighted investment grade government bond index in USD. 
Table 4 shows the results of four regression settings. The important columns to look at are those with the alpha coefficients and their t-values. For Panels A and B it is clear that each of the alphas is statistically indistinguishable from zero. This implies that the statistically significant alphas from the one-factor model in Tables 1, 2, and 3, can be explained by exposures to equity risk factors. Table 4 Panels $C$ and $D$ suggest that currency and bond market factors may be able to explain some alphas (e.g. for frontier markets), but not all. For example, the t-value of the unhedged investment grade alpha is 1.90 , implying significance at the 10 percent level. The general picture from this factor analysis is consistent with Bolla (2017) in the sense that the excess returns for fundamental government bond strategies can be explained by factor exposures.

\section{CONCLUSIONS}

Fundamental indexation in fixed-income markets has recently gained significant interest as an investment strategy. While fundamental indexation has been traditionally investigated in stock markets, the most recent literature has applied the valuation-indifferent weighting approach to bond markets as well. In this paper, we contribute to this strand of the literature by providing a comprehensive risk and return analysis of fundamental weighting schemes of sovereign bond markets investable to foreign investors. Our sample comprises of four different

groups of government bond markets: (i) investment grade local-currency government bond markets; (ii) local-currency emerging government bond markets; (iii) USD denominated 
emerging government bond markets; and (iv) USD denominated frontier government bond markets.

We find that fundamental weighting schemes are not providing superior risk-return characteristics compared to market-capitalisation weighting schemes. We document higher returns for samples in which currency risks are not hedged, suggesting that fundamentals might be more important for currency forwards than bond returns. When we adjust the excess returns for well-known factors from equity, currency or bond markets, the alphas become close to zero and are almost always statistically no longer significant.

Our results do not rule out that fundamental weighting schemes cannot work for government bond markets, but that the four fundamentals discussed in the literature do not seem to generate robust risk-adjusted returns. This might be due to the difficulty of relating a country fundamental size to its bond market returns, as factors such as political risk or the safehaven nature of US and Japanese bond markets might be more important drivers. 


\section{ENDNOTES}

We would like to thank seminar participants of the University of Neuchatel for helpful comments. Swinkels is also affiliated with Robeco Institutional Asset Management. The views expressed in this paper do not necessarily represent the views of Robeco or any of its subsidiaries.

\footnotetext{
${ }^{1}$ Source: Barclays Global Treasury Index Factsheet (4 March 2014). Notice that there are two differences from pure market capitalization weighting prior to 1999 according to the Lehman Brothers Global Treasury Index (October 1998) report. First, bonds issued in the European Currency Unit (ECU) were considered a separate country. Second, to account for investability the Japanese bond market received a lower weight. When we calculate historical market capitalization weighted indexes, we disregard the "country ECU" and use full market capitalization weighting of Japan, also before 1999.

${ }^{2}$ See Eichengreen et al (2005) for a discussion of the ability of country to borrow at longer maturities.

${ }^{3}$ Note that our sample is different from Arnott et al (2010) and it is impossible to reconcile precisely where the differences come from. They mention the Merrill Lynch USD Emerging Markets Sovereign Plus Index has 36 countries, while our sample has 22 countries. Moreover, our country indexes are market cap weighted within each country, while they weight bonds according to their face value.

${ }^{4}$ Kenneth French's data library: http://mba.tuck.dartmouth.edu/pages/faculty/ken.french/data library.html
} 


\section{REFERENCES}

Arnott, R. D, Hsu, J. C., Li, F. and Shepherd, S. S. (2010) Value-indifferent weighting for bonds. Journal of Portfolio Management 36(3): 117-130.

Arnott, R. D., Hsu, J. C. and Moore, P. (2005) Fundamental indexation. Financial Analysts Journal 61(2): 83-99.

Barroso, P. and Santa-Clara, P. (2015) Beyond the carry trade: Optimal currency portfolios. Journal of Financial and Quantitative Analysis 50(5): 1037-1056.

Blitz, D. and Swinkels, L. (2008) Fundamental indexation: An active value strategy in disguise. Journal of Asset Management 9(4): 264-269.

Bolla, L. (2017) Fundamental indexing in global bond markets: The risk exposure explains it all. Financial Analysts Journal 73(1): 101-120.

De Jong, M. and Wu, H. (2014) Fundamental indexation for bond markets. Journal of Risk Finance 15(3): 264-274.

Duyvesteyn, J. and Martens, M. (2014) Emerging government bond market timing. Journal of Fixed Income 23(3): 36-49.

Duyvesteyn, J., Martens, M. and Verwijmeren, P. (2016) Political risk and expected government bond returns. Journal of Empirical Finance 38(A): 498-512.

Eichengreen, B., Hausmann, R. and Panizza, U. (2005) The pain of original sin. In: B. Eichengreen and R. Hausmann (eds.) Other People's Money: Debt Denomination and Financial Instability in Emerging-Market Economies. Chicago: University of Chicago Press, pp. 13-47. 
Fama, E. and French, K. (1993) Common risk factors in the returns on stocks and bonds. Journal of Financial Economics 33(1): 3-56.

Ilmanen, A. (1995) Time-varying expected returns in international bond markets. Journal of Finance 50(2): 481-506.

Ilmanen, A. and Sayood, R. (2002) Quantitative forecasting models and active diversification for international bonds. Journal of Fixed Income 12(3): 40-51.

Kroencke, T., Schindler, F. and Schrimpf, A. (2014) International diversification benefits with foreign exchange investment styles. Review of Finance 18(5): 1847-1883.

Perold, A. (2007) Fundamentally flawed indexing. Financial Analysts Journal 63(6): 31-37.

Piljak, V. and Swinkels, L. (2015) Frontier and emerging government bond markets. Emerging Markets Review, online publication, http://dx.doi.org/10.1016/j.ememar.2015.10.002.

Shepherd, S. (2012) A fundamentally weighted broad-based fixed-income index. Journal of Indexes 15: 20-23.

Thomas, C. and Bennyhoff, D. (2012) A review of alternative approaches to fixed income indexing. Journal of Indexes 15: 10-19. 
Table 1: Performance of fundamentally-weighted portfolios for investment grade government bonds

\begin{tabular}{|c|c|c|c|c|c|c|c|c|c|c|c|}
\hline & Return & Volatility & Yield & Maturity & Divers & Excess return & Alpha & T-stat & Beta & Tracking err & Inform Ratio \\
\hline \multicolumn{12}{|c|}{ Investment Grade - currency hedged - 1987/1-2015/12 } \\
\hline Market cap & 6.17 & 3.19 & 4.33 & 7.91 & 0.19 & - & - & - & - & - & - \\
\hline Population & 6.20 & 3.29 & 5.12 & 7.69 & 0.14 & 0.03 & 0.02 & 0.13 & 1.00 & 0.79 & 0.04 \\
\hline Area & 6.21 & 3.15 & 5.64 & 7.04 & 0.05 & 0.04 & 0.69 & 1.95 & 0.89 & 1.37 & 0.03 \\
\hline GDP & 6.19 & 3.38 & 4.70 & 7.80 & 0.19 & 0.03 & -0.24 & -1.66 & 1.04 & 0.63 & 0.04 \\
\hline Energy cons & 6.21 & 3.85 & 5.23 & 7.94 & 0.25 & 0.04 & -0.57 & -1.75 & 1.10 & 1.63 & 0.03 \\
\hline Composite & 6.20 & 3.32 & 5.17 & 7.62 & 0.11 & 0.03 & -0.02 & -0.14 & 1.01 & 0.79 & 0.04 \\
\hline \multicolumn{12}{|c|}{ Investment Grade - currency unhedged - 1987/1-2015/12 } \\
\hline Market cap & 6.14 & 6.81 & 4.33 & 7.91 & 0.19 & - & - & - & - & - & - \\
\hline Population & 6.78 & 7.02 & 5.12 & 7.69 & 0.14 & 0.64 & 0.83 & 1.58 & 0.97 & 2.42 & 0.26 \\
\hline Area & 7.57 & 8.65 & 5.64 & 7.04 & 0.05 & 1.43 & 0.70 & 0.77 & 1.12 & 4.18 & 0.34 \\
\hline GDP & 6.40 & 6.49 & 4.70 & 7.80 & 0.19 & 0.26 & 0.71 & 2.31 & 0.93 & 1.60 & 0.16 \\
\hline Energy cons & 7.00 & 5.88 & 5.23 & 7.94 & 0.25 & 0.86 & 2.93 & 3.93 & 0.66 & 4.42 & 0.19 \\
\hline Composite & 6.94 & 6.73 & 5.17 & 7.62 & 0.11 & 0.80 & 1.29 & 2.41 & 0.92 & 2.54 & 0.31 \\
\hline
\end{tabular}

Notes: This table contains the return and risk characteristics of fundamental weighting schemes in investment grade government bond markets over the period January 1987 to December 2015. Panel A contains the returns hedged to USD using currency derivatives. Panel B contains the returns in USD without currency hedging. The average bond maturity is in years, average bond yield in percentage per annum, and the diversity score is the Herfindahl-index on the portfolio weights. The average return, volatility, and alphas are in percentages and have been annualized. 
Table 2: Performance of fundamentally-weighted portfolios for local currency emerging government bonds

\begin{tabular}{|c|c|c|c|c|c|c|c|c|c|c|c|}
\hline & Return & Volatility & Yield & Maturity & Divers & Excess return & Alpha & T-stat & Beta & Tracking err & Inform Ratio \\
\hline \multicolumn{12}{|c|}{ Emerging Markets Local Currency - currency hedged - 2008/7-2015/12 } \\
\hline Market cap & 3.45 & 2.72 & 5.57 & 7.88 & 0.13 & - & - & - & - & - & - \\
\hline Population & 3.12 & 3.20 & 6.61 & 8.88 & 0.22 & -0.33 & -0.77 & -2.61 & 1.13 & 0.94 & -0.35 \\
\hline Area & 4.22 & 3.84 & 6.90 & 7.20 & 0.05 & 0.77 & 0.76 & 0.71 & 1.00 & 2.70 & 0.29 \\
\hline GDP & 3.46 & 2.96 & 6.45 & 7.62 & 0.15 & 0.01 & 0.18 & 0.30 & 0.95 & 1.45 & 0.00 \\
\hline Energy cons & 4.95 & 5.21 & 6.36 & 7.70 & 0.11 & 1.50 & 0.89 & 0.60 & 1.18 & 4.14 & 0.36 \\
\hline Composite & 3.94 & 3.51 & 6.58 & 7.85 & 0.08 & 0.49 & 0.27 & 0.35 & 1.06 & 1.98 & 0.25 \\
\hline \multicolumn{12}{|c|}{ Emerging Markets Local Currency - currency unhedged - 2008/7-2015/12 } \\
\hline Market cap & 3.25 & 8.55 & 5.57 & 7.88 & 0.13 & - & - & - & - & - & - \\
\hline Population & 4.44 & 7.56 & 6.61 & 8.88 & 0.22 & 1.19 & 1.71 & 1.79 & 0.84 & 2.72 & 0.44 \\
\hline Area & 4.22 & 11.00 & 6.90 & 7.20 & 0.05 & 0.96 & 0.28 & 0.19 & 1.21 & 4.16 & 0.23 \\
\hline GDP & 3.57 & 9.03 & 6.45 & 7.62 & 0.15 & 0.32 & 0.27 & 0.24 & 1.02 & 2.47 & 0.13 \\
\hline Energy cons & 5.03 & 11.88 & 6.36 & 7.70 & 0.11 & 1.78 & 1.01 & 0.56 & 1.24 & 5.79 & 0.31 \\
\hline Composite & 4.31 & 9.61 & 6.58 & 7.85 & 0.08 & 1.06 & 0.82 & 0.80 & 1.08 & 2.86 & 0.37 \\
\hline
\end{tabular}

Notes: This table contains the return and risk characteristics of fundamental weighting schemes in local currency emerging government bond markets over the period July 2008 to December 2015. Panel A contains the returns hedged to USD using currency derivatives. Panel B contains the returns in USD without currency hedging. The average bond maturity is in years, average bond yield in percentage per annum, and the diversity score is the Herfindahl-index on the portfolio weights. The average return, volatility, and alphas are in percentages and have been annualized. 
Table 3: Performance of fundamentally-weighted portfolios for USD-denominated emerging and frontier government bonds

\begin{tabular}{|c|c|c|c|c|c|c|c|c|c|c|c|}
\hline & Return & Volatility & Yield & Maturity & Divers & Excess return & Alpha & T-stat & Beta & Tracking err & Inform Ratio \\
\hline \multicolumn{12}{|c|}{ Emerging Markets USD - 1994/1-2015/12 } \\
\hline Market cap & 9.84 & 13.46 & 4.37 & 13.49 & 0.14 & - & - & - & - & - & - \\
\hline Population & 11.32 & 14.53 & 4.07 & 13.07 & 0.11 & 1.49 & 1.16 & 1.13 & 1.03 & 4.20 & 0.35 \\
\hline Area & 11.29 & 14.15 & 4.58 & 12.34 & 0.06 & 1.45 & 1.33 & 1.31 & 1.01 & 3.80 & 0.38 \\
\hline GDP & 10.40 & 13.89 & 4.39 & 12.68 & 0.14 & 0.56 & 0.51 & 0.75 & 1.01 & 3.15 & 0.18 \\
\hline Energy cons & 9.82 & 13.11 & 4.42 & 14.20 & 0.20 & -0.01 & 0.75 & 0.62 & 0.92 & 4.37 & 0.00 \\
\hline Composite & 10.71 & 13.70 & 4.36 & 13.07 & 0.10 & 0.87 & 0.94 & 1.22 & 0.99 & 2.97 & 0.29 \\
\hline \multicolumn{12}{|c|}{ Frontier Markets USD - 2002/1-2015/12 } \\
\hline Market cap & 10.94 & 12.86 & 8.34 & 10.09 & 0.12 & - & - & - & - & - & - \\
\hline Population & 10.68 & 10.79 & 7.70 & 7.26 & 0.18 & -0.27 & 2.52 & 1.51 & 0.75 & 5.93 & -0.04 \\
\hline Area & 11.14 & 11.69 & 9.04 & 9.01 & 0.08 & 0.20 & 1.56 & 1.68 & 0.88 & 3.54 & 0.06 \\
\hline GDP & 11.59 & 11.24 & 7.99 & 8.62 & 0.15 & 0.65 & 2.53 & 2.09 & 0.83 & 4.21 & 0.15 \\
\hline Composite & 11.14 & 11.01 & 8.25 & 8.30 & 0.11 & 0.19 & 2.20 & 1.94 & 0.82 & 4.07 & 0.05 \\
\hline
\end{tabular}

Notes: This table contains the return and risk characteristics of fundamental weighting schemes in USDdenominated emerging government bond markets over the period January 1994 to December 2015 and frontier government bond markets over the period January 2002 to December 2015. Returns are in USD. The average bond maturity is in years and the diversity score is the Herfindahl-index on the portfolio weights. The average return, volatility, and alphas are in percentages and have been annualized. 
Table 4: Factor-adjusted excess returns for fundamentally-weighted portfolios

\begin{tabular}{|c|c|c|c|c|c|c|c|c|c|}
\hline \multicolumn{2}{|c|}{ Panel A: US equity factors } & \multicolumn{2}{|c|}{ alpha (\% pa) } & \multicolumn{2}{|c|}{ RMRF } & \multicolumn{2}{|c|}{ SMB } & \multicolumn{2}{|c|}{ HML } \\
\hline Asset class & Hedge & coeff & t-value & coeff & t-value & coeff & t-value & coeff & t-value \\
\hline Investment Grade & $\bar{Y}$ & -0.02 & -0.13 & 0.01 & 1.51 & 0.01 & 1.45 & 0.00 & 0.90 \\
\hline Investment Grade & $\mathrm{N}$ & 0.14 & 0.28 & 0.07 & 4.54 & 0.03 & 2.59 & 0.04 & 2.98 \\
\hline Emerging mkts USD & - & 0.60 & 0.88 & 0.02 & 1.12 & 0.02 & 1.46 & 0.03 & 1.80 \\
\hline Emerg Mkts Local & $\mathrm{Y}$ & -0.16 & -0.21 & 0.06 & 2.49 & -0.02 & -1.08 & -0.04 & -1.21 \\
\hline Emerg Mkts Local & $\mathrm{N}$ & 0.48 & 0.43 & 0.06 & 1.67 & -0.04 & -1.49 & -0.05 & -0.95 \\
\hline Frontier Mkts USD & - & 0.81 & 0.66 & -0.08 & -1.95 & -0.01 & -0.40 & -0.02 & -0.34 \\
\hline \multicolumn{2}{|c|}{ Panel B: Global equity factors } & \multicolumn{2}{|c|}{ alpha (\% pa) } & \multicolumn{2}{|c|}{ RMRF } & \multicolumn{2}{|c|}{ SMB } & \multicolumn{2}{|c|}{ HML } \\
\hline Asset class & Hedge & coeff & t-value & coeff & t-value & coeff & t-value & coeff & t-value \\
\hline Investment Grade & $\mathrm{Y}$ & -0.02 & -0.11 & 0.01 & 2.09 & 0.01 & 2.73 & 0.01 & 1.64 \\
\hline Investment Grade & $\mathrm{N}$ & -0.06 & -0.13 & 0.08 & 5.16 & 0.05 & 2.30 & 0.05 & 2.95 \\
\hline Emerging mkts USD & - & 0.55 & 0.82 & 0.03 & 1.39 & 0.04 & 1.49 & 0.04 & 1.63 \\
\hline Emerg Mkts Local & Y & -0.05 & -0.09 & 0.06 & 3.36 & 0.07 & 1.88 & -0.06 & -1.55 \\
\hline Emerg Mkts Local & $\mathrm{N}$ & 0.50 & 0.53 & 0.06 & 2.00 & 0.08 & 1.50 & -0.08 & -1.37 \\
\hline Frontier Mkts USD & - & 0.74 & 0.60 & -0.09 & -2.29 & -0.03 & -0.54 & 0.05 & 0.85 \\
\hline \multicolumn{2}{|c|}{ Panel C: Currency factors } & \multicolumn{2}{|c|}{ alpha (\% pa) } & \multicolumn{2}{|c|}{ VAL } & \multicolumn{2}{|c|}{ MOM } & \multicolumn{2}{|c|}{ CRY } \\
\hline Asset class & Hedge & coeff & t-value & coeff & t-value & coeff & t-value & coeff & t-value \\
\hline Investment Grade & $\mathrm{Y}$ & 0.05 & 0.35 & 0.00 & 0.31 & -0.01 & -1.23 & 0.00 & 0.78 \\
\hline Investment Grade & $\mathrm{N}$ & 0.23 & 0.64 & -0.01 & -0.39 & -0.03 & -1.59 & 0.19 & 10.63 \\
\hline Emerging mkts USD & - & 1.05 & 1.66 & -0.06 & -1.88 & -0.06 & -1.84 & 0.04 & 1.66 \\
\hline Emerg Mkts Local & $\mathrm{Y}$ & 1.00 & 1.78 & -0.08 & -1.74 & -0.06 & -2.16 & 0.04 & 1.48 \\
\hline Emerg Mkts Local & $\mathrm{N}$ & 1.55 & 1.66 & -0.05 & -0.81 & -0.12 & -2.79 & 0.04 & 1.00 \\
\hline Frontier Mkts USD & - & 0.09 & 0.10 & 0.05 & 0.96 & 0.10 & 1.18 & -0.12 & -2.22 \\
\hline \multicolumn{2}{|l|}{ Panel D: Bond factors } & \multicolumn{2}{|c|}{ alpha (\% pa) } & \multicolumn{2}{|c|}{ TERM } & \multicolumn{2}{|c|}{ DEF } & \multicolumn{2}{|c|}{ DOL } \\
\hline Asset class & Hedge & coeff & t-value & coeff & t-value & coeff & t-value & coeff & t-value \\
\hline Investment Grade & $\bar{Y}$ & -0.04 & -0.29 & 0.02 & 1.07 & 0.02 & 1.34 & 0.00 & 0.44 \\
\hline Investment Grade & $\mathrm{N}$ & 0.79 & 1.90 & -0.05 & -1.10 & 0.38 & 5.35 & -0.07 & -2.84 \\
\hline Emerging mkts USD & - & 0.89 & 1.32 & -0.04 & -0.43 & 0.23 & 2.71 & 0.03 & 0.86 \\
\hline Emerg Mkts Local & $Y$ & -0.09 & -0.19 & 0.08 & 2.02 & 0.24 & 4.38 & 0.04 & 1.70 \\
\hline Emerg Mkts Local & $\mathrm{N}$ & 0.39 & 0.43 & 0.08 & 0.75 & 0.26 & 3.21 & 0.01 & 0.16 \\
\hline Frontier Mkts USD & - & -0.09 & -0.09 & 0.16 & 1.33 & -0.26 & -2.02 & -0.05 & -0.85 \\
\hline
\end{tabular}

Notes: This table contains the factor-adjusted excess returns of each of the samples of fundamental weighting schemes. Panel A refers to the US equity factors and Panel B to the global equity factors (data are from the data library of Kenneth French). The acronym "RMRF" is the equity market minus the shortterm risk-free rate, "SMB" is the Small Minus Big factor, also known as the size effect, and "HML" is High Minus Low, also known as the value effect. Panel C contains the currency factors (data are from Deutsche Bank based on G10 currencies). The acronym "VAL" is currency value (absolute Purchasing Power Parity), "MOM" is momentum, and " $C R Y$ " is nominal interest rate carry. Panel D contains the bond factors. The acronym "TERM" is term factor, "DEF" is default factor, and " $D O L$ " is the currency return of the global market-capitalization-weighted investment grade bond index in USD. The alphas are annualized. T-value shows the t-statistic for the null hypothesis that the parameter is zero. 
Table A.1: Descriptive statistics from the investment grade sample (1987-2015)

\begin{tabular}{|c|c|c|c|c|c|c|c|c|c|c|c|c|c|c|}
\hline & \multicolumn{3}{|c|}{ Index inclusion } & \multicolumn{4}{|c|}{ USD Hedged Returns } & \multicolumn{4}{|c|}{ USD Unhedged Returns } & \multicolumn{3}{|c|}{ Market characteristics } \\
\hline & Enter & Exit & Obs & Average & Volatility & Min & Max & Average & Volatility & Min & Max & Yield & Maturity & Mkt cap \\
\hline Australia & Apr-88 & - & 333 & 5.5 & 4.7 & -3.7 & 5.7 & 8.7 & 11.8 & -14.6 & 10.0 & 6.6 & 5.8 & 74 \\
\hline Austria & Jan-87 & - & 348 & 6.3 & 3.8 & -2.9 & 4.6 & 7.0 & 10.9 & -9.5 & 10.7 & 4.7 & 7.6 & 112 \\
\hline Belgium & Jan-87 & - & 348 & 6.8 & 4.1 & -4.0 & 6.2 & 7.6 & 10.8 & -9.8 & 11.0 & 5.0 & 7.3 & 210 \\
\hline Canada & Jan-87 & - & 348 & 6.5 & 5.0 & -4.7 & 6.2 & 7.5 & 9.0 & -12.2 & 7.8 & 5.5 & 9.3 & 208 \\
\hline Chile & Jan-05 & - & 132 & 3.7 & 3.9 & -2.8 & 6.4 & 4.7 & 12.8 & -15.4 & 10.3 & 5.3 & 4.3 & 4 \\
\hline Czech & Jan-05 & - & 132 & 5.8 & 4.5 & -4.7 & 3.7 & 5.2 & 13.8 & -11.3 & 12.2 & 2.7 & 7.3 & 39 \\
\hline Denmark & Jan-87 & - & 348 & 6.5 & 4.6 & -3.6 & 4.9 & 8.0 & 10.7 & -9.9 & 13.8 & 5.2 & 7.0 & 75 \\
\hline Finland & Jul-91 & - & 294 & 6.5 & 3.9 & -3.2 & 3.7 & 6.4 & 11.2 & -12.7 & 10.6 & 4.5 & 5.6 & 52 \\
\hline France & Jan-87 & - & 348 & 6.4 & 4.4 & -3.6 & 4.4 & 7.5 & 10.8 & -9.3 & 11.6 & 5.0 & 8.4 & 670 \\
\hline Germany & Jan-87 & - & 348 & 6.0 & 3.6 & -2.6 & 3.8 & 6.5 & 10.8 & -10.0 & 11.5 & 4.4 & 7.0 & 708 \\
\hline Greece & Jun-01 & Jul-10 & 109 & 2.3 & 8.0 & -15.0 & 8.2 & 6.9 & 13.5 & -16.8 & 7.9 & 4.2 & 7.7 & 187 \\
\hline Hong Kong & Sep-04 & - & 116 & 3.4 & 2.7 & -2.3 & 3.2 & 3.0 & 2.8 & -2.4 & 3.2 & 2.0 & 3.6 & 4 \\
\hline Hungary & Jan-05 & Dec-11 & 84 & 3.3 & 8.0 & -7.9 & 8.4 & 5.0 & 23.2 & -20.7 & 16.0 & 7.6 & 4.9 & 33 \\
\hline Ireland & Jan-87 & - & 348 & 7.7 & 7.2 & -9.5 & 15.4 & 9.2 & 12.9 & -15.8 & 15.6 & 5.9 & 7.9 & 44 \\
\hline Israel & Jan-12 & - & 48 & 5.5 & 3.4 & -2.6 & 2.9 & 6.0 & 6.7 & -3.5 & 4.0 & 2.2 & 6.4 & 53 \\
\hline Italy & Jan-87 & - & 348 & 7.0 & 4.7 & -5.1 & 5.6 & 8.0 & 12.1 & -13.7 & 10.3 & 6.5 & 6.9 & 700 \\
\hline Japan & Jan-87 & - & 348 & 6.2 & 3.8 & -4.9 & 5.1 & 5.4 & 12.2 & -11.3 & 16.7 & 2.2 & 7.2 & 2,744 \\
\hline Latvia & Feb-14 & - & 23 & 8.5 & 4.5 & -2.9 & 3.5 & -2.7 & 8.6 & -4.0 & 4.4 & 1.2 & 6.7 & 3 \\
\hline Lithuania & Jan-15 & - & 12 & 4.2 & 5.6 & -2.8 & 2.6 & -6.5 & 9.9 & -4.4 & 3.8 & 0.7 & 7.0 & 4 \\
\hline Luxembourg & Jan-10 & - & 72 & 5.0 & 3.8 & -2.7 & 3.2 & 0.9 & 9.5 & -7.0 & 6.7 & 1.5 & 6.8 & 7 \\
\hline Malaysia & Jan-06 & - & 120 & 2.7 & 3.0 & -3.2 & 3.9 & 3.0 & 8.9 & -10.2 & 7.2 & 3.6 & 6.1 & 72 \\
\hline Mexico & Jan-05 & - & 132 & 6.0 & 6.6 & -8.4 & 7.4 & 5.9 & 14.4 & -21.4 & 12.7 & 6.8 & 8.4 & 103 \\
\hline Netherlands & Jan-90 & - & 312 & 6.1 & 3.9 & -3.1 & 4.4 & 6.4 & 10.5 & -10.0 & 11.0 & 4.4 & 7.7 & 222 \\
\hline New Zealand & Jan-87 & - & 348 & 5.5 & 3.9 & -3.1 & 4.5 & 10.5 & 12.2 & -11.9 & 13.1 & 7.1 & 5.1 & 17 \\
\hline Norway & Apr-91 & - & 297 & 5.0 & 3.8 & -3.6 & 4.2 & 5.9 & 11.1 & -11.6 & 9.7 & 4.8 & 5.4 & 23 \\
\hline Poland & Jan-05 & - & 132 & 4.2 & 3.5 & -2.8 & 2.8 & 4.9 & 16.3 & -15.0 & 10.6 & 4.5 & 5.0 & 95 \\
\hline Portugal & Aug-91 & Nov-11 & 244 & 3.9 & 6.1 & -7.4 & 9.0 & 6.4 & 12.4 & -12.3 & 10.9 & 6.2 & 5.8 & 53 \\
\hline Russia & Apr-14 & - & 21 & -1.5 & 12.6 & -11.1 & 6.0 & -26.4 & 38.6 & -27.4 & 19.4 & 10.5 & 5.4 & 44 \\
\hline Singapore & Jan-02 & - & 168 & 3.7 & 3.4 & -2.9 & 3.9 & 5.2 & 7.1 & -7.3 & 5.9 & 1.9 & 6.3 & 43 \\
\hline Slovakia & Jan-05 & - & 132 & 5.7 & 3.9 & -4.6 & 3.4 & 6.4 & 12.2 & -10.8 & 12.2 & 3.0 & 5.9 & 20 \\
\hline Slovenia & Jan-05 & - & 132 & 5.8 & 5.9 & -8.4 & 5.6 & 4.2 & 12.6 & -11.9 & 10.1 & 3.7 & 6.8 & 12 \\
\hline South Africa & Jan-05 & - & 132 & 2.1 & 7.2 & -6.2 & 8.1 & 0.0 & 20.1 & -16.4 & 16.5 & 8.1 & 10.0 & 67 \\
\hline South Korea & Jan-02 & - & 168 & 5.7 & 3.2 & -2.0 & 6.7 & 7.3 & 12.7 & -12.7 & 22.5 & 4.1 & 4.7 & 293 \\
\hline Spain & Jan-89 & - & 324 & 6.7 & 5.0 & -6.8 & 6.9 & 7.6 & 12.0 & -13.1 & 11.9 & 6.0 & 6.7 & 310 \\
\hline Sweden & Jan-87 & - & 348 & 6.0 & 4.6 & -3.9 & 4.5 & 7.0 & 11.4 & -11.3 & 9.8 & 5.8 & 6.2 & 65 \\
\hline Switzerland & Jan-10 & - & 72 & 4.2 & 3.8 & -2.2 & 3.6 & 4.8 & 11.3 & -9.9 & 11.6 & 0.6 & 10.1 & 96 \\
\hline Taiwan & Jan-06 & Dec-11 & 72 & 5.4 & 3.3 & -2.9 & 3.7 & 4.2 & 6.0 & -4.2 & 4.7 & 1.8 & 8.7 & 117 \\
\hline Thailand & Jan-02 & $*$ & 152 & 4.6 & 5.9 & -5.5 & 7.3 & 7.9 & 8.4 & -5.4 & 10.2 & 3.7 & 8.3 & 49 \\
\hline Turkey & Apr-14 & - & 21 & -1.3 & 9.1 & -4.3 & 4.6 & -8.9 & 16.9 & -7.4 & 9.6 & 9.1 & 5.1 & 74 \\
\hline United Kingdom & Jan-87 & - & 348 & 6.2 & 5.9 & -4.8 & 6.5 & 8.4 & 10.8 & -9.0 & 12.6 & 5.7 & 11.8 & 632 \\
\hline United States & Jan-87 & - & 348 & 6.1 & 4.5 & -4.4 & 5.3 & 6.1 & 4.5 & -4.4 & 5.3 & 4.7 & 8.1 & 2,644 \\
\hline
\end{tabular}

* Thailand left the index from Mar-07 to Jun-2008

Notes: This table contains the descriptive statistics from the investment grade sample. Average return and volatility are annualized. Minimum and maximum are monthly. Average yield is in percentage per annum. Average maturity is in years. Market cap is in USD billions. Numbers are calculated over the periods the country was in the index, which is indicated by the first columns. 
Table A.2: Descriptive statistics from the emerging markets (local currency) sample (2008-2015)

\begin{tabular}{|c|c|c|c|c|c|c|c|c|c|c|c|c|c|c|}
\hline & \multicolumn{3}{|c|}{ Index inclusion } & \multicolumn{3}{|c|}{ USD Hedged Returns } & \multicolumn{5}{|c|}{ USD Unhedged Returns } & \multicolumn{3}{|c|}{ Market characteristics } \\
\hline & Enter & Exit & Obs & Average & Volatility & Min & Max & Average & Volatility & Min & Max & Yield & Maturity & Mkt cap \\
\hline Argentina & Jul-08 & Jun-11 & 36 & 22.0 & 47.9 & -50.0 & 38.5 & 33.0 & 52.0 & -55.8 & 40.1 & 29.1 & 2.5 & 0.3 \\
\hline Brazil & Jul-08 & - & 90 & 2.2 & 5.4 & -4.0 & 5.8 & 0.3 & 18.3 & -14.3 & 13.4 & 11.1 & 3.2 & 171.9 \\
\hline Chile & Jul-08 & - & 90 & 3.4 & 4.0 & -2.3 & 6.4 & 3.6 & 13.3 & -15.4 & 10.3 & 4.9 & 4.5 & 4.6 \\
\hline China & Jul-08 & - & 90 & 2.9 & 2.6 & -1.9 & 2.0 & 5.2 & 3.0 & -2.1 & 2.7 & 3.5 & 9.3 & 688.5 \\
\hline Colombia & Jul-08 & - & 90 & 6.5 & 5.6 & -3.8 & 6.0 & 3.7 & 17.5 & -12.4 & 14.8 & 6.8 & 6.3 & 51.3 \\
\hline Croatia & Jul-08 & - & 90 & 4.7 & 4.3 & -5.0 & 4.8 & 1.8 & 13.1 & -11.4 & 8.2 & 5.0 & 4.8 & 3.9 \\
\hline Czech Republic & Jul-08 & - & 90 & 6.6 & 4.9 & -4.7 & 3.7 & 1.1 & 14.9 & -11.3 & 12.2 & 2.3 & 7.6 & 44.5 \\
\hline Egypt & Jul-08 & - & 90 & -5.5 & 6.4 & -5.3 & 5.2 & 7.2 & 7.0 & -5.6 & 5.8 & 12.9 & 3.8 & 24.9 \\
\hline Hungary & Jul-08 & - & 90 & 6.6 & 7.7 & -7.9 & 8.4 & 3.3 & 23.1 & -20.7 & 16.0 & 6.2 & 4.8 & 33.7 \\
\hline India & Jul-08 & - & 90 & 2.5 & 6.7 & -5.5 & 10.6 & 3.8 & 12.3 & -9.9 & 13.9 & 8.1 & 10.2 & 438.0 \\
\hline Indonesia & Jul-08 & - & 90 & 7.0 & 13.0 & -14.1 & 10.8 & 8.8 & 21.9 & -27.3 & 22.7 & 8.5 & 11.3 & 57.8 \\
\hline Israel & Jul-08 & - & 90 & 5.9 & 3.9 & -2.6 & 4.7 & 5.1 & 9.1 & -6.6 & 9.2 & 3.0 & 6.1 & 45.8 \\
\hline Malaysia & Jul-08 & - & 90 & 2.2 & 2.9 & -3.2 & 3.9 & 1.1 & 9.6 & -10.2 & 7.2 & 3.6 & 6.2 & 80.8 \\
\hline Mexico & Jul-08 & - & 90 & 5.6 & 7.1 & -8.4 & 7.4 & 3.4 & 16.3 & -21.4 & 12.7 & 6.2 & 9.2 & 125.3 \\
\hline Nigeria & Apr-13 & - & 33 & 0.7 & 13.3 & -7.1 & 13.9 & 6.9 & 16.7 & -9.3 & 14.7 & 13.4 & 7.3 & 19.3 \\
\hline Peru & Jul-08 & - & 90 & 3.6 & 10.7 & -7.7 & 11.0 & 5.3 & 14.5 & -11.3 & 17.0 & 6.0 & 14.5 & 11.2 \\
\hline Philippines & Jul-08 & - & 90 & 8.2 & 6.9 & -6.7 & 7.7 & 9.7 & 10.4 & -8.8 & 8.6 & 5.1 & 9.5 & 38.8 \\
\hline Poland & Jul-08 & - & 90 & 4.2 & 3.6 & -2.8 & 2.9 & 0.1 & 17.8 & -15.0 & 10.6 & 4.2 & 5.1 & 103.7 \\
\hline Romania & Apr-13 & - & 33 & 5.4 & 3.2 & -1.7 & 2.4 & 0.6 & 9.9 & -4.6 & 6.5 & 3.4 & 4.0 & 19.6 \\
\hline Russia & Jul-08 & - & 90 & -1.6 & 10.0 & -11.1 & 9.4 & -5.7 & 25.2 & -27.4 & 19.4 & 8.3 & 6.8 & 56.9 \\
\hline South Africa & Jul-08 & - & 90 & 3.2 & 7.8 & -6.2 & 8.1 & 1.8 & 21.1 & -16.4 & 16.5 & 8.0 & 10.8 & 72.8 \\
\hline South Korea & Jul-08 & - & 90 & 5.0 & 3.6 & -1.3 & 6.7 & 5.8 & 15.7 & -12.7 & 22.5 & 3.4 & 5.6 & 382.6 \\
\hline Taiwan & Apr-13 & - & 33 & 3.3 & 2.5 & -1.5 & 2.5 & -0.5 & 4.4 & -2.5 & 2.3 & 1.4 & 10.3 & 161.8 \\
\hline Thailand & Jul-08 & - & 90 & 4.9 & 5.6 & -5.2 & 7.3 & 5.9 & 8.4 & -5.4 & 10.2 & 3.3 & 8.8 & 71.9 \\
\hline Turkey & Jul-08 & - & 90 & 4.8 & 8.0 & -5.7 & 6.2 & 2.1 & 18.2 & -22.0 & 13.5 & 10.1 & 3.4 & 62.4 \\
\hline
\end{tabular}

Notes: This table contains the descriptive statistics from the local currency emerging markets sample. Average return and volatility are annualized. Minimum and maximum are monthly. Average yield is in percentage per annum. Average maturity is in years. Market cap is in USD billions. Numbers are calculated over the periods the country was in the index, which is indicated by the first columns. 
Table A.3: Descriptive statistics from the emerging markets USD sample (1994-2015)

\begin{tabular}{|c|c|c|c|c|c|c|c|c|c|c|}
\hline & \multicolumn{3}{|c|}{ Index inclusion } & \multicolumn{4}{|c|}{ USD Hedged Returns } & \multicolumn{3}{|c|}{ Market characteristics } \\
\hline & Enter & Exit & Obs & Average & Volatility & Min & Max & Yield & Maturity & Mkt cap \\
\hline Argentina & Jan-94 & - & 264 & 8.5 & 28.0 & -43.9 & 33.8 & 18.3 & 16.8 & 14 \\
\hline Brazil & Jan-94 & - & 264 & 11.6 & 18.7 & -27.2 & 26.5 & 7.0 & 14.6 & 36 \\
\hline Bulgaria & Jan-94 & Dec-13 & 240 & 13.1 & 18.1 & -36.4 & 25.8 & 4.2 & 9.9 & 2 \\
\hline Colombia & Jun-99 & - & 199 & 10.3 & 10.6 & -12.5 & 12.2 & 6.3 & 11.0 & 10 \\
\hline Croatia & Apr-11 & - & 57 & 7.4 & 9.3 & -7.4 & 5.8 & 5.2 & 6.9 & 7 \\
\hline Ecuador & Jan-94 & Nov-14 & 251 & 15.1 & 29.6 & -55.8 & 28.3 & 11.9 & 15.7 & 2 \\
\hline Egypt & Jun-02 & Apr-08 & 71 & 9.8 & 4.9 & -3.1 & 5.1 & 0.0 & 6.2 & 1 \\
\hline Hungary & May-11 & - & 56 & 8.9 & 10.2 & -5.6 & 9.8 & 5.3 & 10.1 & 10 \\
\hline Indonesia & Nov-06 & - & 110 & 8.3 & 16.7 & -24.2 & 27.0 & 5.8 & 16.4 & 16 \\
\hline Malaysia & Feb-02 & Dec-04 & 35 & 9.8 & 6.7 & -4.0 & 4.2 & 0.0 & 7.1 & 4 \\
\hline Mexico & Jan-94 & - & 264 & 8.7 & 10.4 & -14.6 & 12.9 & 5.5 & 16.6 & 31 \\
\hline Morocco & Jan-94 & Nov-06 & 155 & 9.9 & 15.9 & -30.3 & 22.5 & 5.7 & 4.9 & 2 \\
\hline Nigeria & Jan-94 & Oct-06 & 154 & 14.9 & 18.2 & -25.7 & 15.5 & 0.0 & 19.5 & 2 \\
\hline Panama & Jan-94 & - & 264 & 13.0 & 18.1 & -22.6 & 28.9 & 6.1 & 15.4 & 5 \\
\hline Peru & Jan-94 & - & 264 & 12.7 & 19.5 & -29.9 & 34.5 & 6.1 & 13.9 & 6 \\
\hline Philippines & Jan-94 & $*$ & 257 & 8.9 & 10.3 & -20.4 & 7.8 & 6.2 & 13.3 & 14 \\
\hline Poland & Jan-94 & Apr-07 & 160 & 11.1 & 14.4 & -23.8 & 19.9 & 0.0 & 14.5 & 4 \\
\hline Qatar & Dec-00 & Aug-02 & 21 & 20.3 & 7.3 & -5.0 & 3.8 & 0.0 & 19.3 & 3 \\
\hline Romania & Mar-13 & - & 34 & 6.1 & 7.6 & -4.9 & 6.0 & 4.2 & 10.1 & 5 \\
\hline Russia & Jan-94 & - & 264 & 14.9 & 29.2 & -72.2 & 35.6 & 6.0 & 10.7 & 27 \\
\hline South Africa & Jan-95 & $*$ & 190 & 7.5 & 7.6 & -14.2 & 9.4 & 5.0 & 7.1 & 5 \\
\hline South Korea & May-98 & Jul-02 & 51 & 13.6 & 16.3 & -22.5 & 18.7 & 5.5 & 6.8 & 4 \\
\hline Turkey & Aug-99 & - & 197 & 10.7 & 13.2 & -15.8 & 12.5 & 6.8 & 11.8 & 24 \\
\hline Ukraine & Aug-01 & - & 173 & 11.6 & 24.1 & -33.0 & 38.5 & 9.8 & 4.8 & 4 \\
\hline Venezuela & Jan-94 & - & 264 & 12.1 & 24.0 & -39.1 & 34.0 & 12.8 & 14.4 & 14 \\
\hline
\end{tabular}

* Philippines was not included from Oct-98 to Apr-99, South Africa was not included from Mar-97 to Mar-02

Notes: This table contains the descriptive statistics from the emerging markets USD sample. Average return and volatility are annualized. Minimum and maximum are monthly. Average yield is in percentage per annum, and data on yields only starts in December 2001. Average maturity is in years. Market cap is in USD billions. Numbers are calculated over the periods the country was in the index, which is indicated by the first columns. 
Table A.4: Descriptive statistics from the frontier markets sample (2002-2015)

\begin{tabular}{|c|c|c|c|c|c|c|c|c|c|c|}
\hline & \multicolumn{2}{|c|}{ Index inclusion } & \multicolumn{4}{|c|}{ USD Returns } & \multicolumn{4}{|c|}{ Market characteristics } \\
\hline & Enter & Exit & Obs & Average & Volatility & Min & Max & Yield & Maturity & Mkt cap \\
\hline Algeria & Dec-01 & Feb-03 & 14 & 11.3 & 6.2 & -2.5 & 3.7 & 8.1 & 3.9 & 0.5 \\
\hline Angola & Oct-12 & - & 38 & 1.3 & 7.5 & -6.3 & 3.6 & 5.3 & 3.6 & 1.1 \\
\hline Argentina & Oct-09 & $*$ & 53 & 26.4 & 22.2 & -14.8 & 14.5 & 10.3 & 17.7 & 7.7 \\
\hline Armenia & Oct-13 & - & 26 & 4.9 & 7.6 & -5.3 & 5.2 & 6.0 & 6.6 & 0.8 \\
\hline Honduras & Apr-13 & - & 32 & 9.4 & 10.7 & -9.9 & 6.8 & 7.1 & 7.7 & 0.9 \\
\hline Belarus & Sep-10 & - & 63 & 10.0 & 16.7 & -13.8 & 17.3 & 9.3 & 3.6 & 1.4 \\
\hline Bolivia & Nov-12 & - & 37 & 6.6 & 8.0 & -4.7 & 7.7 & 5.0 & 8.7 & 0.9 \\
\hline Belize & Mar-07 & - & 105 & 8.4 & 26.5 & -26.8 & 34.9 & 12.9 & 14.2 & 0.4 \\
\hline Costa Rica & Oct-14 & - & 14 & -3.8 & 5.9 & -3.6 & 2.8 & 6.7 & 16.1 & 5.9 \\
\hline Dominic Republic & Dec-01 & - & 168 & 10.7 & 17.3 & -40.0 & 21.4 & 8.1 & 7.9 & 1.9 \\
\hline Ecuador & Dec-01 & $*$ & 152 & 11.7 & 26.2 & -55.8 & 22.1 & 12.4 & 11.4 & 2.1 \\
\hline Egypt & May-02 & - & 163 & 6.9 & 8.6 & -12.3 & 7.7 & 5.5 & 7.4 & 1.6 \\
\hline El Salvador & Nov-09 & - & 73 & 5.8 & 8.9 & -6.5 & 5.0 & 6.7 & 15.9 & 4.6 \\
\hline Ethiopia & Dec-14 & - & 12 & -2.8 & 8.8 & -4.6 & 3.9 & 7.0 & 9.4 & 1.0 \\
\hline Gabon & Dec-07 & - & 96 & 7.6 & 17.9 & -31.3 & 14.1 & 6.4 & 7.5 & 1.1 \\
\hline Georgia & Jun-08 & - & 90 & 9.8 & 13.3 & -18.3 & 11.4 & 7.2 & 6.3 & 0.8 \\
\hline Ghana & Oct-07 & - & 98 & 8.6 & 19.3 & -33.2 & 21.7 & 7.9 & 7.2 & 1.1 \\
\hline Guatemala & Jun-12 & - & 42 & 6.3 & 8.4 & -6.9 & 4.5 & 4.7 & 10.5 & 1.3 \\
\hline Indonesia & May-04 & Dec-06 & 31 & 17.0 & 6.5 & -2.6 & 5.0 & 7.0 & 11.3 & 3.0 \\
\hline Iraq & Mar-06 & - & 117 & 9.3 & 17.9 & -26.9 & 16.6 & 8.8 & 13.2 & 2.1 \\
\hline Ivory Coast & Dec-01 & $*$ & 144 & 18.1 & 26.1 & -26.5 & 25.8 & 20.2 & 10.9 & 1.1 \\
\hline Jamaica & Oct-07 & - & 98 & 11.0 & 19.0 & -25.2 & 26.5 & 8.5 & 19.4 & 1.2 \\
\hline Jordan & Jan-11 & $*$ & 46 & 6.9 & 3.9 & -2.3 & 3.8 & 4.0 & 2.8 & 0.7 \\
\hline Kenya & Jul-14 & - & 17 & -4.6 & 7.7 & -6.0 & 3.5 & 6.4 & 7.9 & 2.6 \\
\hline Lebanon & Dec-01 & Sep-02 & 9 & 1.7 & 10.2 & -5.7 & 4.1 & 12.9 & 4.8 & 3.1 \\
\hline Mongolia & Apr-12 & - & 43 & 4.9 & 9.5 & -4.6 & 6.5 & 6.6 & 5.5 & 1.8 \\
\hline Morocco & Dec-01 & Oct-06 & 58 & 6.2 & 3.1 & -2.9 & 3.4 & 5.7 & 2.4 & 1.1 \\
\hline Mozambique & Nov-13 & - & 25 & 1.4 & 8.3 & -4.0 & 4.6 & 8.1 & 3.3 & 0.8 \\
\hline Nigeria & Feb-11 & - & 76 & 5.6 & 8.7 & -8.0 & 8.0 & 4.2 & 7.2 & 1.3 \\
\hline Pakistan & Dec-01 & $*$ & 152 & 11.7 & 16.8 & -25.9 & 17.1 & 9.0 & 5.1 & 1.2 \\
\hline Paraguay & Feb-13 & - & 34 & 3.5 & 7.8 & -4.8 & 4.8 & 5.1 & 15.0 & 1.1 \\
\hline Senegal & May-11 & - & 55 & 7.7 & 10.5 & -11.5 & 8.1 & 6.8 & 8.1 & 0.7 \\
\hline Serbia & Apr-05 & Dec-09 & 56 & 9.0 & 16.9 & -15.5 & 20.6 & 7.5 & 9.9 & 1.0 \\
\hline Sri Lanka & Nov-07 & - & 97 & 9.8 & 16.3 & -26.5 & 21.0 & 7.3 & 5.4 & 3.2 \\
\hline Tanzania & May-13 & - & 31 & 3.5 & 5.6 & -2.7 & 3.8 & 6.1 & 3.5 & 0.6 \\
\hline Tunisia & Feb-15 & - & 10 & -13.5 & 8.8 & -5.4 & 2.3 & 6.1 & 9.5 & 1.0 \\
\hline Ukraine & Dec-01 & Feb-11* & 90 & 13.2 & 7.7 & -5.1 & 9.1 & 6.1 & 4.8 & 5.1 \\
\hline Uruguay & May-02 & Mar-07 & 58 & 22.7 & 28.9 & -33.6 & 28.5 & 10.3 & 18.9 & 2.5 \\
\hline Vietnam & Nov-05 & - & 121 & 7.5 & 12.2 & -23.7 & 14.6 & 5.6 & 6.9 & 1.4 \\
\hline Zambia & Oct-12 & - & 38 & -4.5 & 12.5 & -11.2 & 6.2 & 7.2 & 8.9 & 1.4 \\
\hline
\end{tabular}

* These countries leave the index for the periods between brackets: Argentina (Aug-11/Mar-13), Ecuador (Sep-06/Nov-07), Ivory Coast (Jun-08/Apr-10), Jordan (Nov-14/Oct-15), Pakistan (Feb-03/Apr-04), Ukraine (Mar-08/Sep-09).

Notes: This table contains the descriptive statistics from the frontier markets USD sample. Average return and volatility are annualized. Minimum and maximum are monthly. Average yield is in percentage per annum. Average maturity is in years. Market cap is in USD billions. Numbers are calculated over the periods the country was in the index, which is indicated by the first columns. 